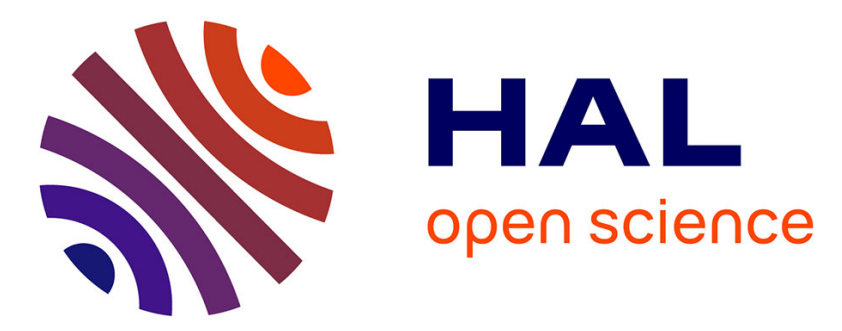

\title{
Average daily nitrate and nitrite intake in the Belgian population older than 15 years
}

\author{
Liesbeth Temme, Stefanie Marie Vandevijvere, Christine Vinkx, Inge \\ Huybrechts, Leo Goeyens, Herman van Oyen
}

\section{- To cite this version:}

Liesbeth Temme, Stefanie Marie Vandevijvere, Christine Vinkx, Inge Huybrechts, Leo Goeyens, et al.. Average daily nitrate and nitrite intake in the Belgian population older than 15 years. Food Additives and Contaminants, 2011, 28 (9), pp.1193-1204. 10.1080/19440049.2011.584072 . hal-00714934

\section{HAL Id: hal-00714934 \\ https://hal.science/hal-00714934}

Submitted on 6 Jul 2012

HAL is a multi-disciplinary open access archive for the deposit and dissemination of scientific research documents, whether they are published or not. The documents may come from teaching and research institutions in France or abroad, or from public or private research centers.
L'archive ouverte pluridisciplinaire HAL, est destinée au dépôt et à la diffusion de documents scientifiques de niveau recherche, publiés ou non, émanant des établissements d'enseignement et de recherche français ou étrangers, des laboratoires publics ou privés. 


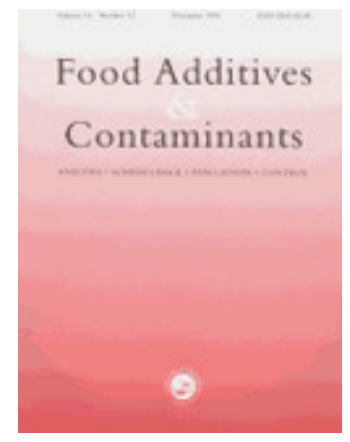

\section{Average daily nitrate and nitrite intake in the Belgian population older than 15 years}

\begin{tabular}{|r|l|}
\hline Journal: & Food Additives and Contaminants \\
\hline Manuscript ID: & TFAC-2011-121 \\
\hline Danuscript Type: & Original Research Paper \\
\hline Author: & 14-Mar-2011 \\
\hline Complete List of Authors: & $\begin{array}{l}\text { Temme, Liesbeth; Scientific Institute of Public Health, Epidemiology } \\
\text { Vandevijere, Stefanie; Scientific Institute of Public Health, } \\
\text { Epidemiology } \\
\text { Vinkx, Christine; Federal Public Service of Health, Food Chain } \\
\text { Safety and Environment } \\
\text { Huybrechts, Inge; University of Ghent } \\
\text { Goeyens, Leo; Scientific Institute of Public Health, Epidemiology } \\
\text { Van Oyen, Herman; Scientific Institute of Public Health, } \\
\text { Epidemiology }\end{array}$ \\
\hline Methods/Techniques: & HPLC, Total diet studies \\
\hline Additives/Contaminants: & Nitrate, Nitrite \\
\hline Food Types: & $\begin{array}{l}\text { The aim of this study was to assess the dietary intake of nitrate and } \\
\text { nitrite in Belgium. The nitrate content of processed vegetables, } \\
\text { cheeses and meat products was analyzed. These data were } \\
\text { completed by data from non-targeted official control and from } \\
\text { literature. In addition, the nitrite content of meat products was } \\
\text { measured. Concentration data for nitrate and nitrite were linked to } \\
\text { food consumption data of the Belgian Food Consumption Survey. } \\
\text { This study included 3245 respondents, aged 15 years and older. } \\
\text { Food intakes were estimated by a repeated 24-h recall using EPIC- } \\
\text { SOFT. Only respondents with two completed 24-hour recalls } \\
\text { (n=3083) were included in the analysis. For the intake assessment, } \\
\text { average concentration data and individual consumption data were } \\
\text { combined. Usual intake of nitrate/nitrite was calculated using the }\end{array}$ \\
\hline Abstracted
\end{tabular}




\section{SCHOLARONE Manuscripts}

NUSSER method. The mean usual daily intake of nitrate was 1.38 $\mathrm{mg} / \mathrm{kg}$ bodyweight (bw)/day and the usual daily intake at the 97.5 percentile was $2.76 \mathrm{mg} / \mathrm{kg}$ bw/day. Exposure of the Belgian population to nitrate at mean intake corresponded to $38 \%$ of the ADI (while $76 \%$ at the 97.5 percentile). For the average consumer half of the intake was derived from vegetables (especially lettuce) and $20 \%$ from water and water-based drinks. Average daily intake of nitrate and nitrite from cheese and meat products was low (respectively $0.2 \%$ and $6 \%$ of ADI at average intake). Scenario analyses with higher consumption of vegetables or higher nitrate concentration in tap water showed a significant higher intake of nitrate. Whether this is beneficial or harmful must be further assessed. 


\section{Average daily nitrate and nitrite intake in the Belgian}

\section{2 population older than 15 years}

3

4 Elisabeth HM Temme ${ }^{1}$, Stefanie Vandevijvere ${ }^{1}$, Christine Vinkx ${ }^{3}$, Inge Huybrechts ${ }^{4}$, Leo

5 Goeyens $^{2}$, Herman Van Oyen ${ }^{1}$

$6 \quad{ }^{1}$ Scientific Institute of Public Health - Unit of Epidemiology, Brussels

$7 \quad{ }^{2}$ Scientific Institute of Public Health - Unit of Food Services, Brussels

$8 \quad{ }^{3}$ Federal Public Service Health, Food Chain Safety and Environment, Brussels

$9 \quad{ }^{4}$ Department of Public Health, Ghent University

10

Author for correspondence and to who requests for reprints should be addressed:

12 Stefanie Vandevijvere, Scientific Institute of Public Health, Unit of Epidemiology, Brussels,

13 J. Wytsmanstraat 14, B-1050 Brussels, Belgium. Phone: +32 2642 5752. Fax: +32 2642 14 5410. E-mail: Stefanie.vandevijvere@wiv-isp.be

Running title: Nitrate and nitrite intake in Belgium

\section{KEYWORDS}

16 Nitrate, nitrite, food consumption survey, exposure assessment, ADI, Belgium 


\section{ABSTRACT}

20 The aim of this study was to assess the dietary intake of nitrate and nitrite in Belgium. The 21 nitrate content of processed vegetables, cheeses and meat products was analyzed. These data 22 were completed by data from non-targeted official control and from literature. In addition, the 23 nitrite content of meat products was measured. Concentration data for nitrate and nitrite were 24 linked to food consumption data of the Belgian Food Consumption Survey. This study 25 included 3245 respondents, aged 15 years and older. Food intakes were estimated by a 26 repeated 24-h recall using EPIC-SOFT. Only respondents with two completed 24-hour recalls $27(\mathrm{n}=3083)$ were included in the analysis. For the intake assessment, average concentration data 28 and individual consumption data were combined. Usual intake of nitrate/nitrite was calculated 29 using the NUSSER method. The mean usual daily intake of nitrate was $1.38 \mathrm{mg} / \mathrm{kg}$ 30 bodyweight (bw)/day and the usual daily intake at the 97.5 percentile was $2.76 \mathrm{mg} / \mathrm{kg}$ bw/day. 31 Exposure of the Belgian population to nitrate at mean intake corresponded to $38 \%$ of the ADI 32 (while $76 \%$ at the 97.5 percentile). For the average consumer half of the intake was derived 33 from vegetables (especially lettuce) and $20 \%$ from water and water-based drinks. Average 34 daily intake of nitrate and nitrite from cheese and meat products was low (respectively $0.2 \%$ 35 and $6 \%$ of $\mathrm{ADI}$ at average intake). Scenario analyses with higher consumption of vegetables 36 or higher nitrate concentration in tap water showed a significant higher intake of nitrate. 37 Whether this is beneficial or harmful must be further assessed. 


\section{INTRODUCTION}

Recently the role of nitrate and nitrite as healthful dietary components has been reconsidered (Hord et al. 2009; Lundberg et al. 2006; Lundberg 2009; Lundberg et al. 2009; Lundberg et al. 2011; Lundberg and Weitzberg 2009; Lundberg and Weitzberg 2010). Nitrate and nitrite rich food sources may play a physiological role in vascular and immune function. Higher intakes are hypothesized to be associated with lower blood pressure and a better cardiovascular function (Lundberg et al., 2006; Lundberg, 2009; Lundberg et al., 2011).

Till now the risk of nitrate and nitrite has been emphasized. Nitrate toxicity is, for adults, thought to be related to the in vivo conversion to nitrite after ingestion (Hartman 1983). Nitrite reacts with amines at the stomach $\mathrm{pH}$ to form nitrosamines that are known as carcinogenic compounds (Office fédéral de la santé publique Division science des aliments 2000). The EC Scientific Committee on Food (SCF) considered in their independent expert committee in 1995 the safety of nitrate and recommended an Acceptable Daily Intake (ADI) of 3.65 mg per $\mathrm{kg}$ bodyweight per day (equivalent to $220 \mathrm{mg}$ per day for an adult of $60 \mathrm{~kg}$ ) (JECFA Food Additives Series 50, Nitrate and Nitrite). The ADI for nitrite is $0.07 \mathrm{mg}$ per kg bodyweight per day, which is equivalent to $4.2 \mathrm{mg}$ per day for an individual weighing $60 \mathrm{~kg}$.

Nitrate and nitrite are allowed as preservative by European Authorities (European Parliament and Council Directive No 95/2/EC of 20 February 1995).

It is worthwhile to assess the exposure of the Belgian population to nitrate and nitrite and its major sources, both because of possible beneficial as well as harmful aspects.

The nitrate intake by the Belgian consumer was estimated previously in 1994 (Dejonckheere et al. 1994). Additive intake was not taken into consideration in that study. At that moment actual food intake data were not available, since no national dietary survey had been carried out. Consumption data were estimated from household purchase data. 
62 The objective of the present study was to re-estimate the nitrate and nitrite intake via the diet 63 in Belgium by use of actual concentrations and individual food consumption data. To 64 complement the existing data on occurrence of nitrate in unprepared vegetables and fruits, 65 obtained from Dejonckheere et al (Dejonckheere et al., 1994), analyses were performed in 66 processed vegetables and fruits (canned, jarred or deep frozen, as available on the market).

67 For some products, for example spinach, including the processing in intake assessment is 68 especially important because of the higher consumption of frozen compared to fresh spinach 69 in Belgium. To our knowledge the effects of processing methods on nitrate concentrations in 70 vegetables available on the Belgium market have not been evaluated before. In addition, food 71 groups (cheese, meat products) were analyzed in which nitrate or nitrite is added as a food 72 additive.

\section{METHODS}

\section{Study design}

76 For the analysis of nitrate in foods, the focus was on fruits and vegetables, potato (products), 77 cheese and processed meat. Food items for nitrate or nitrite analyses were chosen on the basis 78 of data on nitrate concentrations present in foods available in Belgium: from literature, from 79 the Belgian Federal Agency for the Safety of the Food Chain or available product 80 information. Already existing data on nitrate concentrations in fresh vegetables and fruits 81 from Belgium were used from Dejonckheere et al (Dejonckheere et al., 1994), as well as more 82 recent data of fresh vegetables from non-targeted official control programmes. In case both 83 consulted sources contained data for a certain vegetable or fruit, the most recent data were 84 used. In Table 1 it can be found for each vegetable or fruit which source for concentration 85 data has been used. 
86 There seemed to be no important evolution in time in concentrations of nitrate in vegetables.

87 Additional analyses were performed that could add to these already existing data. The focus 88 was on the nitrate content of differently processed vegetables and fruits and nitrate used as 89 additive in cheese and processed meats. The average nitrate content of bottled water, as 90 communicated by the industry to the Federal Public Service of Health $(2.6 \mathrm{mg} / \mathrm{L}$; average of 91 positive concentrations), was used for mineral and source waters. For other drinks based on 92 water (coffee, tea, soup), the nitrate concentration was assumed to be $21 \mathrm{mg} / \mathrm{l}$, which is the 93 average nitrate concentration as communicated by official distributors of tap water in Brussels 94 and Wallonia. For the analysis of nitrite, focus was on the group of processed meats because 95 of the high allowed levels (residual concentration of $50-175 \mathrm{mg} / \mathrm{kg}$ ) compared to its presence 96 in other food items (European Parliament and Council Directive No 95/2/EC of 20 February 97 1995).

98 Afterwards, the nitrate and nitrite concentrations of the different foods were linked to 99 corresponding foods recorded in the individual food consumption survey after applying 100 correction factors for peeling, washing, and home cooking as done by Dejonckheere 101 (Dejonckheere et al., 1994). The effect of processing was taken into account for vegetables 102 using the corrected concentration value whenever the processing or conservation mode of the 103 food was registered in the food consumption survey. The utilized factors can be found in 104 Table 1.

105 106 107 108 
109 Nitrate and nitrite concentration of selected foods

\section{Food sampling}

111 Efforts were made to ensure representative concentration data. Samples of cheese and meat

112 products, however, were targeted towards products for which nitrate or nitrite use was known

113 from the label. Sampling was performed from January till March 2006 in the 5 most 114 frequented supermarket chains (6 for the frozen products).

115 Different seasons were not taken into account because it is impossible to determine the time

116 of harvest. Moreover nitrate or nitrite addition to meat or cheese is not a seasonal practice. A 117 total of 49 vegetable and fruit, 15 cheese and 43 processed meat pooled samples were 118 analyzed for nitrate and 15 cheese and 43 processed meat pooled samples for nitrite. A pooled 119 sample contained up to 16 different samples, each from a different trade mark and/or a 120 different kind of food within the food group. After sampling and before treatment of samples 121 they were stored in the fridge or in the freezer $\left(-18^{\circ} \mathrm{C}\right.$ or less $)$ depending on the preservation 122 mode at sampling. If the analyses were not conducted on the same day, the sample was stored 123 deep frozen $\left(-18^{\circ} \mathrm{C}\right.$ or less) for a maximum time of 1 month. The stability of nitrate during 124 this type of storage has been demonstrated elsewhere (Chung et al. 2004). In case of fresh 125 products, the edible part was analyzed (eg. celeriac was peeled).

\section{Nitrate and nitrite quantification method}

127 Individual samples from the same kind of foods (type and preservation mode) but from 128 different supermarkets and manufacturers were mixed in equivalent proportions to obtain a 129 pooled sample. $200 \mathrm{~g}$ of each sample was ground with a Robocoup cutter model 3000 within 130 a minimum period of time to avoid conversion of nitrate into nitrite (bacterial reduction) or 
131 nitrite into nitrate (air oxidation). All samples of the same types were mixed together in a

132 pooled sample and two $200 \mathrm{~g}$ portions were preserved until analysis.

133

134 All reagents solutions were prepared from analytical grade reagents with vacuum filtered 135 water showing less residual resistivity than $18.2{\mathrm{M} \Omega ~ \mathrm{~cm}^{-1}}^{-1}$ from a Millipore MilliQ Reagent 136 Grade System coupled after a Millipore Elix 100 deionised water production system). 10g of 137 the pooled homogenized sample was mixed at about 15 000rpm in an Ultra-Turrax T25 (IKA, 138 Germany) with $100 \mathrm{ml}$ of a $6.55 \mathrm{mmol}^{-1}$ Borax (Fluka, Switzerland) buffer heated at $60^{\circ} \mathrm{C}$ just 139 before extraction. The Ultraturax was rinsed 2 times with a total of $40 \mathrm{ml}$ extraction solution 140 which is then added to the sample extract. $2 \mathrm{ml}$ of a $15 \%$ potassium hexacyanoferrate (II) 141 (Merck, Germany) and $2 \mathrm{ml}$ of $30 \%$ zinc sulfate (Merck, Germany) are added to the extract 142 which is shaken after each addition. After cooling, the extract is brought up to $200.0 \mathrm{ml}$ with 143 MilliQ water. The extract was filtered through a $0.22 \mu \mathrm{m}$ PVDF syringe filter after 144 centrifugation at 7 000rpm.

146 The final extract was injected into an High Performance Liquid Chromatography (HPLC) 147 system formed of a 232XL injector (Gilson, USA), a 9010 HPLC pump (Varian inc., 148 Australia), a column oven (Alltech, USA), a UV detector model 785A (Applied Biosystem 149 PerkinElmer Inc., USA) operated at $220 \mathrm{~nm}$ and a signal acquisition system formed of a 150 Star800 interface and Galaxy version 1.7 (Varian Inc, Australia). Further calibration and 151 quality assurance calculations were done in Microsoft Excel version 10 SP3. The analytes 152 were injected isocratically at $1.0 \mathrm{ml} \mathrm{min}^{-1}$ on a Lichrospher100 RP18 250mm length, 4.6mm 153 internal diameter and $5 \mu \mathrm{m}$ particles thickness maintained at $35^{\circ} \mathrm{C}$. The eluent was constituted 154 by a mix of tetrabutylammonium sulfate $50 \mathrm{mmol} \mathrm{l}^{-1}$ (Fluka, Switzerland), purified water and 155 methanol Lichrosolve grade (Merck, Germany) in 10/68/22 proportion. 
156 The signal (peak high, in this case) for a particular compound in an unknown sample was

157 compared with the one of the same compound in a standard solution of known concentration.

158 To prove the linearity of the detection system, a minimum of 7 different standard

159 concentrations were used in the range 0.1 to $200 \mathrm{mg} \mathrm{l}^{-1}$ of $\mathrm{NO}_{3}^{-}$or $\mathrm{NO}_{2}^{-}$. The calibration

160 solutions were prepared from purified water with resistivity lower then $18.2 \mathrm{M} \Omega \mathrm{cm}^{-1}$ and

$161 \mathrm{NaNO}_{3}$ (Riedel-deHaën, Switzerland) and $\mathrm{NaNO}_{2}$ (Riedel-deHaën, Switzerland) reagent

162 grade or $1000 \mathrm{mg} \mathrm{l}^{-1}$ solutions. Those solutions were prepared on each series of analysis. The

163 relationship between signal and concentration was linear with a first order polynomial

164 equation between 0.1 and $50 \mathrm{mg}^{-1}$ and also between 10 and $200 \mathrm{mg} \mathrm{l}^{-1}$. A second order

165 polynomial regression can also be used over the all range. The purity, accuracy and stability

166 (after 18 days) of the standards were checked with a 1/20 dilution of ready certified standard

167 solutions for ion chromatography $1000 \mathrm{mg} \mathrm{l}^{-1}$ (Fluka, Switzerland) in $\mathrm{NO}_{3}{ }^{-}$or $\mathrm{NO}_{2}{ }^{-}$ions. The

168 recovered amounts were $97.7 \%$ nitrate and $101.8 \%$ nitrite. Each series of analysis was

169 composed of a calibration curve, solvent blank, sample blank, control sample, samples and

170 control standard.

171

172 The method precision was validated by injecting 9 replicates of the same sample over 3 day's

173 of work. This was done at 3 different concentrations chosen in regards of the expected

174 concentration in the type of food targeted. There were 3 different matrices representing meat

175 products, vegetables and cheese (chopped pork meat, tomatoes and Emmental). For nitrate,

176 the precision was greater in meat and vegetable products (less than $5 \%$ variation for the

177 highest concentrations tested) than in cheese where very high variation was found at

178 concentration near the quantification limit (nearly 90\%). In the case of nitrite, the precision

179 was lower than for nitrate between 25 and $50 \mathrm{mg}^{-1}$ (maximum variation result of $36 \%$ but

180 once again, for concentrations near the quantification limit, the variation observed (in

181 vegetable) was higher $(66 \%)$. 
182 The quantification limit was $5.0 \mathrm{mg} \mathrm{kg}^{-1}$ for nitrate and $6.7 \mathrm{mg} \mathrm{kg}^{-1}$ for nitrite. A selectivity test

183 of the method has been carried out and demonstrated that the separation of nitrate and nitrite 184 was achieved from phosphate, chloride, ascorbic acid and citric acid that can also be present 185 in the sample in plus minus high quantities.

186

187 Food consumption data

188 The food consumption data were obtained from the Belgian Food Consumption Survey (FCS)

1892004 (De Vriese et al. 2005). The target population covered all Belgian inhabitants of 15 190 years or older with no upper limit of age. The sample was stratified by province and included 1913245 participants randomly selected from the National Register.

192

193 Information on dietary intake was collected by a repeated non-consecutive $24 \mathrm{~h}$ recall in 194 combination with a food frequency questionnaire. The respondents reported the quantity of all 195 foods and beverages consumed during the preceding day. Quantification of foods and recipes 196 was performed using photographs, standard units or $\mathrm{ml} / \mathrm{g}$. In order to get information on the 197 within-person variation, two non-consecutive $24 \mathrm{~h}$ recalls per respondent were collected. The 198 24h recall was carried out using the standardized EPIC-SOFT program (Slimani and Valsta 199 2002).

200

201 Statistical analyses

202 Only respondents with two complete $24-\mathrm{h}$ recall interviews were included in the analyses $(\mathrm{n}=$ $2033083 ; 1546$ men and 1537 women). The individual intake of nitrate and nitrite from a 204 certain food product was estimated by:

$$
y_{i}(m g / k g b w / d a y)=\frac{c_{i} \times x_{i}}{b w_{i}},
$$


206 where $y_{i}$ is the intake of nitrate/nitrite by individual $i$ from a particular food (in $\mathrm{mg}$ per $\mathrm{kg}$ 207 bodyweight and per interview day), $x_{i}$ is the consumption of a certain food by individual $i$ $208(\mathrm{~kg}), c_{i}$ is the concentration of nitrate/nitrite in that food (mg per $\mathrm{kg}$; when nitrate 209 concentrations were below the limit of detection (LOD), $0 \mathrm{mg} \mathrm{kg}^{-1}$ concentration was 210 applied)(Kroes et al. 2002) and $b w_{i}$ is the self-reported body weight of individual $i(\mathrm{~kg})$. To 211 estimate the total intake of nitrate/nitrite per group of foods and/or per day, individual daily 212 intakes of the contaminant from different foods were summed. The concentration in a food is 213 either a concentration in a pooled sample, or an average concentration from different 214 individual and/or pooled samples.

216 The usual nitrate intake distribution was estimated with the Nusser method (Nusser et al. 217 1996) using the C-side program (Iowa State University 1996). Several statistical methods are 218 available to estimate usual intake distributions with the correct mean, variance and skewness. 219 These statistical procedures adjust for within-person or day-to-day variability. The Nusser 220 method eliminates the within-individual variance and additionally transforms the data to 221 obtain approximately normally distributed data. The method is suitable to estimate usual 222 intake distributions in a population both for normally and non-normally distributed foods and 223 nutrients. 


\section{RESULTS}

\section{Nitrate concentrations of (conserved) foods}

227 The nitrate concentrations in fruits and vegetables used in the exposure assessment are given 228 in table 1 , for cheese and meat products in table 2.

\section{$229 \quad$ Vegetables and fruits}

230 The highest nitrate concentrations were found for lettuce, some other leafy vegetables and 231 celery, with large differences depending on the method of processing. The highest nitrate 232 concentrations for all vegetables studied (except for peas and carrots) were found in fresh 233 vegetables followed by frozen vegetables and canned vegetables or vegetables in glass 234 respectively. Nitrate concentration in peas in glass or can was 3.8 times higher than in fresh 235 peas while nitrate was not detected in frozen peas. Nitrate concentration in fresh carrots was 236 higher than in carrots in glass or can and frozen carrots. Nitrate concentrations in frozen 237 vegetables were on average 43\% (19\%-62\%) and in canned or glass packed vegetables $69 \%$ 238 (54\%-91\%) lower than in fresh vegetables.

239 In the previous intake calculations of nitrate performed by Dejonckheere et al (Dejonckheere 240 et al., 1994), only vegetables were considered, for which data were available for the 3 241 different conservation methods (fresh, frozen and canned or glass).

243 In order to estimate the variation in concentrations obtained in pooled samples, the analysis 244 was done within samples of the same processing method for some vegetables, namely endive, 245 beans with pods and celery. Nitrate $\left(\mathrm{NO}_{3}{ }^{-}\right)$concentrations in frozen endive $(\mathrm{n}=2)$ were $2461264 \pm 119 \mathrm{mg} / \mathrm{kg}(\mathrm{CV}$ of $9.4 \%)$, in frozen endive with added cream $(\mathrm{n}=9) 758 \pm 95 \mathrm{mg} / \mathrm{kg}(\mathrm{CV}$ 247 of $13 \%)$ and in white celery, in can or glass ( $\mathrm{n}=5) 757 \pm 173 \mathrm{mg} / \mathrm{kg}(\mathrm{CV}$ of $23 \%)$. 
248 The largest variations were observed for frozen beans $(n=12)$ with a nitrate concentration of $249429 \pm 250 \mathrm{mg} / \mathrm{kg}(\mathrm{CV}$ of $59 \%)$ and beans in glass jar $(\mathrm{n}=10) 264 \pm 79 \mathrm{mg} / \mathrm{kg}(\mathrm{CV}$ of $30 \%)$. The 250 average concentrations measured in these additional analyses, however, were similar to the 251 pooled sample analyses as reported in table 1, except for white celery. 252

253 Nitrate and nitrite additive use in cheese and meat products

254 Some cheeses were analyzed and the concentrations found in pooled samples are shown in

255 table 2. Some cheeses were not pooled because they are special foods ("appellations") of 256 controlled origin. The average concentration of 9 pooled Gouda half- and old cheeses was 257 about the same as the average concentration of 11 young ones. This was an unexpected result 258 because half and old Gouda are more dry than the young one, so the concentration was 259 expected to be higher. More investigations should be done on individual analysis basis.

260 Meat products were analyzed for nitrate after pooling of individual samples. The results are 261 given in table 2. Due to the huge number of meat products available on the market, it was 262 decided in some cases to make more than one pooled sample in order to represent major types 263 of processed meat products. Not more than 15 individual samples were pooled per sample.

265 The standard deviation of the mean nitrate concentration found in samples of the same meat 266 product (samples within a pooled sample) varied from $11 \%$ of the mean concentration in the 267 case of creamy pie to up to $81 \%$ of the mean concentration in the case of raw meat sausages. 268 Those results suggested that depending on the manufacturer the concentration can vary 269 substantially. The obtained results of nitrite concentrations in meat products are also given in 270 table 2. The measured concentrations were between 5 and $34 \mathrm{mg} \mathrm{kg}^{-1}$. 
271 This result was unexpected because of the relatively high allowed residual concentrations (50$272175 \mathrm{mg} / \mathrm{kg})$. Even for bacon, the concentration was very low $\left(5 \mathrm{mg} \mathrm{kg}^{-1}\right)$.

\section{Nitrate intake}

274 The average age of the population was $47 \pm 19 \mathrm{yr}: 46 \pm 18 \mathrm{yr}$ for men and $48 \pm 19 \mathrm{yr}$ for women. 275 The average self-reported weight of the population was $(71 \pm 14) \mathrm{kg}$; $(78 \pm 13) \mathrm{kg}$ for men and 276 (65 \pm 12$) \mathrm{kg}$ for women (De Vriese et al. 2006)

277

278 The estimated average usual daily intake of selected foods (g/day) is given in table 3 . The 279 combination of individual consumption data and average concentration data for the different 280 food items regrouped in categories is given in table 4. The total estimated average daily intake 281 of nitrate from these foods was $1.38 \mathrm{mg} / \mathrm{kg}$ bw/day (or $96 \mathrm{mg} / \mathrm{day}$ ) when beverages (non282 alcoholic and soup) were included and $0.885 \mathrm{mg} / \mathrm{kg}$ bw/day (or $61 \mathrm{mg} /$ day) on average when 283 only potatoes, vegetables and fruits were included. When all foods were considered, half of 284 the mean usual nitrate intake was from vegetables and $20 \%$ from non-alcoholic beverages.

285 Potatoes and soups (soups were supposed to consist of $30 \%$ vegetable mix and $70 \%$ tap water, 286 resulting in a calculated nitrate concentration for soups of $105 \mathrm{mg} / \mathrm{kg}$ ) contributed each for 287 around $10 \%$ to the daily nitrate intake. Of the vegetables, lettuce was the main contributor to 288 total nitrate intake, both because of its high nitrate concentration and high consumption in the 289 Belgian population. Carrots had a relatively lower nitrate concentration but a high 290 consumption; on the other hand spinach has a high nitrate content but was consumed only by 291 a small part of the population. The category 'other (mixtures) of vegetables' consisted of 292 vegetables, which were not specified by the respondent, during the $24-\mathrm{h}$ recalls, or mixtures 293 of vegetables. 
295 Fruits contributed only little to nitrate intake. Of the drinks almost half of the nitrate is from 296 the tap water used to brew coffee and tea. The estimated daily food additive intake of nitrate, 297 from meat products and cheese, was $1.16 \mathrm{mg}$ (or $0.013 \mathrm{mg} / \mathrm{kg} \mathrm{bw} /$ day), which was only $0.9 \%$ 298 of the total average daily intake. The ADI was not exceeded even in the high percentiles of 299 intake, although it should be noted that average and not maximum concentrations of nitrate 300 were used in the different foods At total average intake, the intake represented $38 \%$ of ADI 301 and at the 97.5 percentile of intake it corresponded to $76 \%$ of ADI.

\section{Nitrite intake from processed meat}

304 Table 5 shows the estimated usual food additive intake of nitrite from meat products, which 305 was on average $0.24 \mathrm{mg} / \mathrm{day}$ or $0.003 \mathrm{mg} / \mathrm{kg} \mathrm{bw} /$ day, representing $6 \%$ of the ADI. Although 306 boiled ham had a nitrite concentration near to the LOD, because of the high consumption of 307 this meat product, it was the main source of intake (24\%).

308

\section{DISCUSSION}

\section{Nitrate concentrations of foods}

311 Concentrations of nitrate were the highest for fresh rucola (rocket salad), lamb's lettuce,

312 lettuce, radish, celery, spinach and endive (Table 1). Nitrate concentrations of most vegetables 313 analyzed during this study fall within the wide range of values reported before by 314 Dejonckheere et al, 1996) However, other vegetables contained higher nitrate concentrations 315 (e.g. turnip) and for others no concentrations have been reported so far (rhubarb, courgette) 316 (Belitz H-D et al. 1999; Chung et al. 2003; Penttilä PL 1995; Petersen and Stoltze 1999; 317 Tamme et al. 2006). 
318 Concentrations of nitrate in vegetables vary, in addition, according to the processing method

319 with the highest concentrations in fresh, then frozen and the lowest in vegetables preserved in 320 can or glass. This was confirmed in this study, except for peas and carrots. The nitrate content 321 in processed carrots (frozen, canned or jarred) was lower than in fresh carrots, but the level in 322 frozen carrots was not higher than the level in canned or jarred carrots. A likely explanation is 323 that nitrate is lost during blanching of frozen vegetables and into the water in the jar, as far as 324 the nitrate content in the vegetable is higher than in water. For vegetables with low nitrate 325 content such as peas and carrots, a transfer of nitrate to the vegetables might be possible from 326 the added water used for preparation (if the nitrate concentration in water is higher than that in 327 the vegetables). Variation of concentrations even within the same vegetable and processing 328 method is high; within the group of processed vegetables studied, the highest variation of $32958 \%$ was noticed for frozen beans with pods. This spread may be explained by different 330 varieties, growing and processing conditions. Food additive nitrate concentrations of cheese 331 and meat products are low compared to the possible contamination observed in vegetables 332 and tap water.

\section{Nitrate intake}

334 In the current intake assessment, using individual consumption data and average 335 concentration data, the nitrate intake was estimated to be $96 \mathrm{mg}$ per day or $1.38 \mathrm{mg} / \mathrm{kg}$ bw/day 336 (38\% of the ADI). The intake assessment took into account potatoes, vegetables and fruits, 337 processed meat, cheese, water and drinks based on water. Half of the intake was from 338 vegetables, of which $20 \%$ from lettuce. When comparing these figures with previous ones, 339 different aspects have to be taken into account, like the type of food consumption data and the 340 food groups included in the analyses. 
342 Comparing our results with the results of the previous Belgian intake estimate (Dejonckheere

343 et al., 1994), a higher intake of $2.11 \mathrm{mg} / \mathrm{kg}$ bw/day was recorded in the previous Belgian

344 study. The data used in the latter study were derived from household budget surveys and food

345 balance sheets for Belgium. These types of food consumption data are collected at group level

346 with no information on the actual amounts consumed by individuals, including waste,

347 resulting thus in a higher estimate of the daily intake. In addition, dietary patterns might have

348 changed during the past years. In the previous study for instance, the intake of vegetables and

349 potatoes was 202 and 250g per person per day respectively (Dejonckheere et al., 1994), while

350 the consumed quantities currently measured were only 132 and 98 g per person per day,

351 respectively.

352 The recommended intake of vegetables (Vlaams Instituut voor Gezondheidspromotie 2007) is 353 much higher than the amounts actually consumed. In a scenario where vegetable intake would 354 comply with the recommended amount of $350 \mathrm{~g} /$ day instead of $132 \mathrm{~g} / \mathrm{day}$, the mean intake of 355 nitrate would be $2.49 \mathrm{mg} / \mathrm{kg}$ bw/day ( $68 \%$ of ADI) instead of $1.38 \mathrm{mg} / \mathrm{kg}$ bw/day.

356 As the ADI of nitrate will not be exceeded by complying with the recommendation for 357 vegetable consumption, the beneficial effects of increasing vegetable intake outweigh the 358 possible adverse effects. In the current food consumption survey only $1 \%$ of the respondents 359 reached the recommendations for vegetables (Vandevijvere et al. 2008). In addition, certain

360 nutritional habits, such as changing especially in the winter season from green house head 361 lettuce to iceberg lettuce with lower nitrate concentration could reduce intake. Among 362 beneficial effects might be the effects of nitrate and nitrite themselves. Recent prospective 363 epidemiologic studies have shown that green leafy vegetables are among the foods most 364 protective against coronary heart disease and ischemic stroke risk (Joshipura et al. 1999). The 365 authors hypothesize that: the content of inorganic nitrate in certain vegetables and fruit can 366 provide a physiologic substrate for reduction to nitrite, nitric oxide, and other metabolic 
367 products $(\mathrm{NOx})$ that produce vasodilatation, decrease blood pressure, and support 368 cardiovascular function (McKnight et al. 1999). These studies call into question the rationale 369 for recommendations to limit nitrate and nitrite intake from plant foods. EFSA's 370 Contaminants Panel (CONTAM) has assessed the risks and benefits to consumers from 371 nitrates in vegetables and concluded that the beneficial effects of eating vegetables and fruit 372 outweigh potential risk to human health from exposure to nitrate through vegetables.

373

374 In studies with similar individual dietary assessments as in the current study (24h recall, food 375 records), intake is largely influenced by whether water and water based drinks are taken into 376 account. Taking into account only potatoes, vegetables and fruits and some drinks, results are 377 similar to a Finnish study that reported an intake of $55 \mathrm{mg} / \mathrm{day}$ (or $0.92 \mathrm{mg} / \mathrm{kg}$ bw/day) 378 (Penttilä et al. 1990). Penttilä et al (Penttilä et al., 1990) probably underestimated the intake 379 of nitrate by drinks. Calculating back the intake of coffee and soft drinks is on average $38050 \mathrm{ml} /$ day. In the present study the intake of coffee was $270 \mathrm{ml} /$ day. Another important 381 difference is that the nitrate content of water was estimated to be $10 \mathrm{mg} / \mathrm{kg}$ whereas in the 382 current study an average content of $21 \mathrm{mg} / \mathrm{L}$ was used. Individual food consumption data 383 (dietary history) estimated a total intake of $77 \mathrm{mg}$ /day from foods for Finnish adults (Dich et 384 al. 1996). Nitrate from drinking water was not taken into account. Of this estimate $90 \%$ was 385 derived from vegetables (including potatoes). Our results are very similar; the average 386 estimated nitrate intake is $76 \mathrm{mg}$ when the non alcoholic beverages are not taken into account, $38760 \%$ of this intake is from vegetables.

389 In a recent French study among adults (Menard et al. 2008) the average nitrate intake was 3.7 $390 \mathrm{mg}$ per $\mathrm{kg} \mathrm{bw/day}$ or $40 \%$ of the ADI.. The major contributors were, vegetables (24\% of $391 \mathrm{ADI})$, potatoes (5\% of ADI), and water (5\% of ADI). Intake of nitrite was $0.06 \mathrm{mg}$ per $\mathrm{kg}$ 
392 bw/day (33-67\% of the ADI), with major contributions of additive food vectors. Another 393 dietary assessment method was used (7-day food record) than in our study. 396 concentration of nitrate in water was on average $21 \mathrm{mg} / \mathrm{L}$. This average is based on 397 concentrations communicated for tap water in the Wallonia and Brussels regions. For 398 different food groups (soft drinks, juices reconstituted or not) it was assumed that they 399 consisted for $100 \%$ of drinking water, which might be an overestimation. A maximal level of $40050 \mathrm{mg} / \mathrm{kg}$ is allowed for drinking water. In case of this upper level, intakes will be higher 401 (average of $1.76 \mathrm{mg} / \mathrm{kg}$ bw/day instead of $1.38 \mathrm{mg} / \mathrm{kg}$ bw/day or $48 \%$ of ADI). Drinking water 402 in Belgium, however, rarely exceeds this limit although regional differences might exist (van 403 Grinsven et al. 2006).

404

405 In a combined situation of both an assumed median vegetable intake which equals the 406 recommended vegetable intake and water with maximum nitrate concentrations, the average 407 nitrate intake will be $2.59 \mathrm{mg} / \mathrm{kg}$ bw/day $(75.7 \%$ of $\mathrm{ADI})$ instead of $1.38 \mathrm{mg} / \mathrm{kg}$ bw/day. It is 408 thus clear that the recommendation for vegetable consumption is safe with regard to nitrate 409 intake. In such unlikely scenario in which all consumers increase their vegetable intake with 410 the same percentage as the median consumer would do to reach the recommended vegetable 411 intake, and in which all tap water (also used to make coffee, tea, to reconstitute fruit juice and 412 to make soft drinks) reaches the maximum nitrate level, almost $25 \%$ of the adult population in 413 Belgium would exceed the acceptable daily intake. Whether this is beneficial or harmful must 414 be further assessed. 


\section{$417 \quad$ Nitrite}

418 Intake of the additive nitrite from processed meats was $0.24 \mathrm{mg} / \mathrm{day}$. This is only $6 \%$ of the 419 ADI. For nitrite the main issue is the use as additive. Further evaluation must be focused on 420 more vulnerable groups such as children, with possibly high consumption of certain products 421 like ham sausages.

422

423 Methodological issues

424 In this study, the intake of nitrate and nitrite in the adult Belgian was estimated as accurately 425 as possible. The nitrate concentration data for potatoes, vegetables and fruits took into 426 account, if available, waste and preparation method. Consumption data are reported as 427 consumed. In many cases, however, information on correction factors is not available, 428 resulting in an overestimation of the nitrate concentration.

430 In only a very limited number of foods analyzed, only some cheeses, nitrate concentrations 431 were below the limit of detection and in these cases a concentration of $0 \mathrm{mg} / \mathrm{kg}$ was applied. 432 This could have lead to an underestimation of the intake but the foods concerned were not 433 consumed at a high level and not frequently. Additionally, the mean concentration values 434 were used in the intake assessment; no maximum concentrations.

435 The variation in concentration among the different variety or brands of one particular food 436 could expose some consumers to higher nitrate concentrations in time than the mean 437 concentration value if brands or varieties are not regularly varied and if consumers choose 438 regularly those ones with the higher nitrate concentrations. 
440 A common problem in dietary assessment in general (Zhang et al. 1999; Zhang et al. 2000) 441 and also in the present study is the possibility of underreporting of foods. It was estimated, 442 based on energy requirements, that $12 \%$ of the respondents under recorded their real food 443 intake. This might affect nitrate intake assessment. On the other hand large efforts were made 444 in this study to include a representative sample of the Belgian population older than 15 years 445 of age by choosing respondents among all categories of age, regions and social classes of 446 Belgium. In addition, this study is reliable because it takes into account the most important 447 foods consumed in Belgium and food concentrations were reported not only in the case of an 448 additive usage but also when it could be assumed to be present on a natural way 449 ("contaminant") in the food.

\section{CONCLUSION}

451 Usual exposure to nitrate in Belgian adults was on average $96 \mathrm{mg}$ per day or $1.38 \mathrm{mg} / \mathrm{kg}$ 452 bw/day and represented $38 \%$ of the ADI. Half of the intake was derived from vegetables 453 (especially lettuce) and $20 \%$ of water and drinks based on water. Daily intake of the food 454 additives nitrate ( $0.2 \%$ of ADI) and nitrite ( $6 \%$ of ADI) from cheese and meat products was 455 low. Scenario analyses showed the possible effect of a higher vegetable intake and higher 456 nitrate content of water on estimated nitrate intake.

\section{ACKNOWLEDGEMENTS}

460 The study was funded by the Federal Public Service of Health, Food Chain Safety and 461 Environment. 


\section{References}

Belitz H-D, Grosch W, Schieberle P. 1999. Food Chemistry. Springer-Verlag, Berlin.

Chung JC, Chou SS, Hwang DF. 2004. Changes in nitrate and nitrite content of four vegetables during storage at refrigerated and ambient temperatures. Food Addit Contam 21: 317-322.

Chung SY, Kim JS, Kim M, Hong MK, Lee JO, Kim CM, Song IS. 2003. Survey of nitrate and nitrite contents of vegetables grown in Korea. Food Addit Contam 20: 621-628.

De Vriese S, Debacker G, de Henauw S, Huybrechts I, Kornitzer M, Leveque A, Moreau M, Van Oyen H. 2005. The Belgian food consumption survey: aims, design and methods.

Archives of Public Health 63: 1-16.

De Vriese S, Huybrechts I, Moreau M, Van Oyen H. 2006. De Belgische

Voedselconsumptiepeiling 1 - 2004 : Rapport. Wetenschappelijk Instituut Volksgezondheid, Brussels, Belgium.

Dejonckheere W, Steurbaut W, Drieghe R, Verstraeten R, Braekman H. 1994. Nitrate in food commodities of vegetable origin and the total diet in Belgium (1992-1993). Microbiologie Aliments - Nutrition 12: 359-370.

Dich J, Jarvinen R, Knekt P, Penttila PL. 1996. Dietary intakes of nitrate, nitrite and NDMA in the Finnish Mobile Clinic Health Examination Survey. Food Addit Contam 13: 541-552.

Hartman PE. 1983. Review: putative mutagens and carcinogens in foods. I. Nitrate/nitrite ingestion and gastric cancer mortality. Environ Mutagen 5: 111-121.

Hord NG, Tang Y, Bryan NS. 2009. Food sources of nitrates and nitrites: the physiologic context for potential health benefits. Am J Clin Nutr 90: 1-10.

Iowa State University. 1996. A user's guide to C-SIDE. Software for Intake Distribution Estimation. Department of Statistics and Center for Agricultural and Rural Development; Iowa State University

Joshipura KJ, Ascherio A, Manson JE, Stampfer MJ, Rimm EB, Speizer FE, Hennekens CH, Spiegelman D, Willett WC. 1999. Fruit and vegetable intake in relation to risk of ischemic stroke. Journal of the American Medical Association 282: 1233-1239.

Kroes R, Muller D, Lambe J, Lowik MR, van KJ, Kleiner J, Massey R, Mayer S, Urieta I, Verger P, Visconti A. 2002. Assessment of intake from the diet. Food Chem Toxicol 40: 327385.

Lundberg JO. 2009. Cardiovascular prevention by dietary nitrate and nitrite. Am J Physiol Heart Circ Physiol 296: H1221-H1223.

Lundberg JO, Carlstrom M, Larsen FJ, Weitzberg E. 2011. Roles of dietary inorganic nitrate in cardiovascular health and disease. Cardiovasc Res 89: 525-532.

Lundberg JO, Feelisch M, Bjorne H, Jansson EA, Weitzberg E. 2006. Cardioprotective effects of vegetables: is nitrate the answer? Nitric Oxide 15: 359-362. 
Lundberg JO, Gladwin MT, Ahluwalia A, Benjamin N, Bryan NS, Butler A, Cabrales P, Fago A, Feelisch M, Ford PC, Freeman BA, Frenneaux M, Friedman J, Kelm M, Kevil CG, KimShapiro DB, Kozlov AV, Lancaster JR, Jr., Lefer DJ, McColl K, McCurry K, Patel RP, Petersson J, Rassaf T, Reutov VP, Richter-Addo GB, Schechter A, Shiva S, Tsuchiya K, van Faassen EE, Webb AJ, Zuckerbraun BS, Zweier JL, Weitzberg E. 2009. Nitrate and nitrite in biology, nutrition and therapeutics. Nat Chem Biol 5: 865-869.

Lundberg JO, Weitzberg E. 2009. NO generation from inorganic nitrate and nitrite: Role in physiology, nutrition and therapeutics. Arch Pharm Res 32: 1119-1126.

Lundberg JO, Weitzberg E. 2010. The biological role of nitrate and nitrite: the times they are a-changin'. Nitric Oxide 22: 61-63.

McKnight GM, Duncan CW, Leifert C, Golden MH. 1999. Dietary nitrate in man: friend or foe? British Journal of Nutrition 81: 349-358.

Menard C, Heraud F, Volatier JL, Leblanc JC. 2008. Assessment of dietary exposure of nitrate and nitrite in France. Food Addit Contam Part A Chem Anal Control Expo Risk Assess 25: 971-988.

Nusser SM, Carriquiry AL, Dodd KW, Fuller WA. 1996. A semiparametric transformation approach to estimating usual daily intake distributions. Journal of the American Statistical Association 91: 1440-1449.

Office fédéral de la santé publique Division science des aliments. 2000. Nitrates dans les légumes: nouvelle évaluation de leur impact sur la santé. Office fédéral de la santé publique, Switzerland.

Penttilä PL. 1995. Estimation of food additive and pesticide intakes by means of a stepwise method (dissertation).

Penttilä PL, Rasanen L, Kimppa S. 1990. Nitrate, nitrite, and N-nitroso compounds in Finnish foods and the estimation of the dietary intakes. Z Lebensm Unters Forsch 190: 336-340.

Petersen A, Stoltze S. 1999. Nitrate and nitrite in vegetables on the Danish market: content and intake. Food Addit Contam 16: 291-299.

Slimani N, Valsta L. 2002. Perspectives of using the EPIC-SOFT programme in the context of pan- European nutritional monitoring surveys: methodological and practical implications. European Journal of clinical Nutrition 56 Suppl 2: S63-S74.

Tamme T, Reinik M, Roasto M, Juhkam K, Tenno T, Kiis A. 2006. Nitrates and nitrites in vegetables and vegetable-based products and their intakes by the Estonian population. Food Addit Contam 23: 355-361.

van Grinsven HJ, Ward MH, Benjamin N, de Kok TM. 2006. Does the evidence about health risks associated with nitrate ingestion warrant an increase of the nitrate standard for drinking water? Environ Health 2006 Sep 21;5:26 5: 26.

Vandevijvere S, De Vriese S, Huybrechts I, Moreau M, Temme E, de Henauw S, De Backer G, Kornitzer M, Leveque A, Van Oyen H. 2008. The gap between food-based dietary guidelines and usual food consumption in Belgium, 2004. Public Health Nutr 1-9. 
Vlaams Instituut voor Gezondheidspromotie. 2007. De Actieve voedingsdriehoek.

Zhang J, Temme EH, Kesteloot H. 1999. Sex ratio of total energy intake in adults: an analysis of dietary surveys. Eur J Clin Nutr 53: 542-551.

Zhang J, Temme EH, Sasaki S, Kesteloot H. 2000. Under- and overreporting of energy intake using urinary cations as biomarkers: relation to body mass index. Am J Epidemiol 152: 453462. 
Table 1. Concentrations of nitrate $\left(\left[\mathrm{NO}_{3}{ }^{-}\right](\mathrm{mg} / \mathrm{kg})\right.$ in selected vegetables, potatoes and fruit.

\begin{tabular}{|c|c|c|c|c|c|}
\hline Food item & $\begin{array}{l}\text { Number } \\
\text { of } \\
\text { samples }\end{array}$ & $\begin{array}{c}\text { Number } \\
\text { of } \\
\text { samples } \\
\text { per } \\
\text { pooled } \\
\text { sample } \\
\end{array}$ & $\begin{array}{l}\text { Preparation or } \\
\text { Preparation correction }\end{array}$ & $\begin{array}{r}{\left[\mathrm{NO}_{3}^{-}\right]} \\
(\mathrm{mg} / \mathrm{kg}) \\
\text { after } \\
\text { correction }\end{array}$ & Source \\
\hline \multicolumn{6}{|l|}{ VEGETABLES } \\
\hline Salad Rocket & 6 & & Washed without exterior leaves (-13.9\%) & 3488 & FASFC(2006) \\
\hline Lettuce, lambs & 41 & & Washed (-9.4\%) & 2736 & FASFC(2006) \\
\hline Lettuce & 305 & & Washed without exterior leaves (-13.9\%) & 2351 & FASFC (2006) \\
\hline Lettuce, Iceberg & 12 & & Washed without exterior leaves (-13.9\%) & 1084 & FASFC (2006) \\
\hline Celery (green, white) & 73 & & & 2110 & FASFC (2006) \\
\hline Celery white, frozen & & 1 & & 1624 & IPH (2006) \\
\hline Celery white, can/glass & & 5 & & 964 & IPH (2006) \\
\hline Spinach & 44 & & Stewed without stems and midribs $(-30.6 \%)$ & 1509 & FASFC (2006) \\
\hline Spinach, frozen & & 8 & & 846 & IPH (2006) \\
\hline $\begin{array}{l}\text { Spinach with cream, } \\
\text { frozen }\end{array}$ & & 8 & & 702 & IPH (2006) \\
\hline Spinach, can/glass & & 5 & 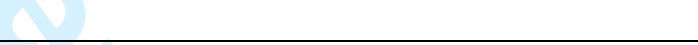 & 496 & IPH (2006) \\
\hline Endive & 36 & & Washed $(-11.4 \%)$ & 1414 & FASFC (2006) \\
\hline Endive, frozen & & 1 & & 1320 & IPH (2006) \\
\hline $\begin{array}{l}\text { Endive with } \\
\text { cream,frozen }\end{array}$ & & 4 & & 684 & IPH (2006) \\
\hline Celeriac & & 3 & Peeled & 901 & IPH (2006) \\
\hline Celeriac, frozen & & 1 & & 334 & IPH (2006) \\
\hline Celeriac, can/glass & & 3 & & 83 & IPH (2006) \\
\hline Leek & & & & 841 & $*$ \\
\hline Leek green, frozen & & 3 & & 348 & IPH (2006) \\
\hline Leek white, frozen & & 3 & & 286 & IPH (2006) \\
\hline Beans with pods & & & & 585 & $*$ \\
\hline $\begin{array}{l}\text { Beans with pods, } \\
\text { frozen }\end{array}$ & & 9 & & 432 & IPH (2006) \\
\hline $\begin{array}{l}\text { Beans with pods, } \\
\text { can/glass }\end{array}$ & & 16 & & 244 & IPH (2006) \\
\hline Carrot & & & Stewed $(-25 \%)$ & 348 & $*$ \\
\hline Carrot, can/glass & & 9 & & 176 & IPH (2006) \\
\hline Carrot, frozen & & 6 & & 132 & IPH (2006) \\
\hline $\begin{array}{l}\text { Brussels sprouts, } \\
\text { can/glass }\end{array}$ & & 1 & & 874 & IPH (2006) \\
\hline Cabbage, white, frozen & & 1 & & 127 & IPH (2006) \\
\hline Cabbage, red, frozen & & 5 & & 115 & IPH (2006) \\
\hline Cabbage, savoy, frozen & & 1 & & 89 & IPH (2006) \\
\hline Cauliflower, frozen & & 5 & & 77 & IPH (2006) \\
\hline Sauerkraut, can/glass & & 8 & & 65 & IPH (2006) \\
\hline Cabbage, red, can/glass & & 9 & & 20 & IPH (2006) \\
\hline Chinese cabbage, fresh & & 1 & Without exterior leaves and hart & 0 & IPH (2006) \\
\hline Brussels sprouts, frozen & & 5 & & 0 & IPH (2006) \\
\hline Broccoli, frozen & & 5 & & 0 & IPH (2006) \\
\hline Mushrooms & & & & 58 & $*$ \\
\hline Mushrooms, frozen & & 4 & & 47 & IPH (2006) \\
\hline Mushrooms, can/ glass & & 13 & & 10 & IPH (2006) \\
\hline
\end{tabular}


1

3

\begin{tabular}{|c|c|c|c|c|c|}
\hline Food item & $\begin{array}{l}\text { Number } \\
\text { of } \\
\text { samples }\end{array}$ & $\begin{array}{c}\text { Number } \\
\text { of } \\
\text { samples } \\
\text { per } \\
\text { pooled } \\
\text { sample } \\
\end{array}$ & $\begin{array}{l}\text { Preparation or } \\
\text { Preparation correction }\end{array}$ & $\begin{array}{r}{\left[\mathrm{NO}_{3}^{-}\right]} \\
(\mathrm{mg} / \mathrm{kg}) \\
\text { after } \\
\text { correction }\end{array}$ & Source \\
\hline Tomato, paste & & 10 & & 53 & IPH (2006) \\
\hline Tomato, fresh & & & & 36 & $*$ \\
\hline Tomato, can/glass & & 14 & & 9 & IPH (2006) \\
\hline Salsify, frozen & & 4 & & 104 & IPH (2006) \\
\hline Salsify, can/glass & 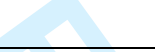 & 11 & & 34 & IPH (2006) \\
\hline Peas, can/glass & 7 & 13 & & 57 & IPH (2006) \\
\hline Peas & & & & 15 & $*$ \\
\hline Peas, frozen & & 7 & & 0 & IPH (2006) \\
\hline Other vegetables fresh & 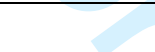 & & & & \\
\hline Radish & & & & 2136 & * \\
\hline Turnip & & 3 & Without exterior leaves & 1018 & IPH (2006) \\
\hline Courgette & & 5 & Not peeled & 897 & IPH (2006) \\
\hline Rhubarbe & & 1 & With peel & 572 & IPH (2006) \\
\hline Cucumber & & & & 344 & * \\
\hline Aubergine & & 5 & Not peeled & 302 & IPH (2006) \\
\hline Sweet pepper & & & $a v^{2}$ & 93 & $*$ \\
\hline Chicory & & & & 77 & $*$ \\
\hline Onion & & & & 59 & $*$ \\
\hline $\begin{array}{l}\text { Other vegetables } \\
\text { can/glass }\end{array}$ & & & 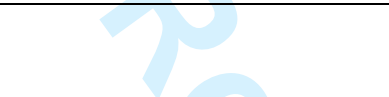 & & \\
\hline Beetroot, can/glass & & 3 & & 999 & IPH (2006) \\
\hline Gherkin, can/glass & & 12 & & 55 & IPH (2006) \\
\hline Legumes, can/glass & & 8 & & 40 & IPH (2006) \\
\hline Asparagus, can/glass & & 7 & & 0 & IPH (2006) \\
\hline \multicolumn{6}{|l|}{$\begin{array}{l}\text { Other vegetables, } \\
\text { frozen }\end{array}$} \\
\hline Persil, frozen & & 3 & & 1173 & IPH (2006) \\
\hline $\begin{array}{l}\text { Mix of vegetables } \\
\text { (other than peas and } \\
\text { carrots) }\end{array}$ & & 15 & & 300 & IPH (2006) \\
\hline \multicolumn{6}{|l|}{ POTATOES } \\
\hline Fresh potatoes & & & Peeled (-33.8\%) & 102 & $*$ \\
\hline Potatoe crips & & 13 & & 223 & IPH (2006) \\
\hline $\begin{array}{l}\text { Potato croquettes, } \\
\text { frozen }\end{array}$ & & 11 & Frozen & 72 & IPH (2006) \\
\hline French fries, frozen & & 13 & Frozen & 40 & IPH (2006) \\
\hline \multicolumn{6}{|l|}{ FRUITS } \\
\hline Melon & & & Peeled $(-41.1 \%)$ & 221 & $*$ \\
\hline Strawberry & & & & 156 & $*$ \\
\hline Banana & & & Peeled (-61.9\%) & 153 & $*$ \\
\hline Grape & & & & 46 & $*$ \\
\hline Pear & & & & 14 & $*$ \\
\hline Orange & & & & 13 & $*$ \\
\hline Nectarine & & & & 12 & $*$ \\
\hline Apple & & & & 11 & $*$ \\
\hline Peach & & & & 10 & $*$ \\
\hline Kiwi & & 7 & Peeled & 0 & IPH (2006) \\
\hline
\end{tabular}


2

3

6

Food item

Number Number

$\begin{array}{lll}\text { of } & \text { of } & \text { Preparation or } \\ \text { samples } & \text { samples } & \text { Preparation cor }\end{array}$ per Preparation correction

pooled sample

Pineapple, can/glass 10 $7 \quad$ IPH (2006)

IPH2006 : Sampling and analyses performed by the scientific institute of Public health in the frame of the current study

* Dejonckheere et al, 1996

FASFC 2006: Non-targeted official control data from 2004-2005 received from the Belgian Federal Agency for Safety of the Food Chain, unpublished data, personal communication. 
Table 2. Concentration of nitrate $\left(\mathrm{NO}_{3}{ }^{-}(\mathrm{mg} / \mathrm{kg})\right.$ and nitrite $\left.\left(\mathrm{NO}_{2}{ }^{-}\right](\mathrm{mg} / \mathrm{kg})\right)$ in meat products and cheese $^{\mathrm{a}}$.

\begin{tabular}{|c|c|c|c|c|}
\hline Food item & $\begin{array}{l}\text { Number } \\
\text { of } \\
\text { samples } \\
\text { in pools }\end{array}$ & $\begin{array}{l}\text { Number } \\
\text { of } \\
\text { pooled } \\
\text { samples }\end{array}$ & {$\left[\mathrm{NO}_{3}^{-}\right](\mathrm{mg} / \mathrm{kg})$} & {$\left[\mathrm{NO}_{2}^{-}\right](\mathrm{mg} / \mathrm{kg})$} \\
\hline \multicolumn{5}{|l|}{ Meat products } \\
\hline Sausages, ham & 11 & 1 & 31.6 & 34.4 \\
\hline Sausages, boiled & 24 & 3 & $35.3 \pm 5.9$ & $21.6 \pm 11.8$ \\
\hline Sausage, raw meat & 81 & 8 & $40.4 \pm 32.9$ & $13.2 \pm 7.7$ \\
\hline Sausages boiled in can & 45 & 6 & $23.5 \pm 6.7$ & $12.0 \pm 3.1$ \\
\hline Poultry meat & 33 & 4 & $32.0 \pm 11.6$ & $19.5 \pm 7.8$ \\
\hline Horse meat & 6 & 1 & 187.0 & 18.2 \\
\hline Beef & 6 & 1 & 59.1 & 17.8 \\
\hline Ham, raw & 43 & 6 & $149.0 \pm 76.4$ & $8.5 \pm 2.5$ \\
\hline Ham, boiled & 22 & 3 & $18.0 \pm 4.2$ & $6.6 \pm 0.8$ \\
\hline Ham, boiled Magistral & 8 & 1 & 14,7 & $<\mathrm{LOQ}^{* *}$ \\
\hline Hure & 13 & 1 & 18.4 & 8.8 \\
\hline Liver paste & 24 & 3 & $57.3 \pm 6.5$ & $6.6 \pm 1.3$ \\
\hline Lard & 21 & 3 & $34.4 \pm 10.9$ & $5.3 \pm 0.3$ \\
\hline Bacon & 8 & 1 & 85.9 & 4.8 \\
\hline Meat loaf & 10 & 1 & 50.9 & $<\mathrm{LOQ}^{* *}$ \\
\hline \multicolumn{5}{|l|}{ Cheese } \\
\hline Milner & 5 & 1 & 25.6 & $<\mathrm{LOQ}^{* *}$ \\
\hline Gouda, semi-matured & 11 & 1 & 15.8 & $<\mathrm{LOQ}^{* *}$ \\
\hline Gouda, matured & 9 & 1 & 16.1 & $<\mathrm{LOQ}^{* *}$ \\
\hline Emmentaler & 9 & 1 & $<\mathrm{LOQ}^{*}$ & $<\mathrm{LOQ}^{* *}$ \\
\hline Edam, Leerdam, Maasdam & 6 & 1 & 7.0 & $<\mathrm{LOQ}^{* *}$ \\
\hline Gruyères & 5 & 1 & $<\mathrm{LOQ}^{*}$ & $<\mathrm{LOQ}^{* *}$ \\
\hline Parmesan & 5 & 1 & $<\mathrm{LOQ}^{*}$ & $<\mathrm{LOQ}^{* *}$ \\
\hline Melted cheeses & 9 & 1 & 16.0 & $<\mathrm{LOQ}^{* *}$ \\
\hline Passendale & 1 & 1 & 9.3 & $<\mathrm{LOQ}^{* *}$ \\
\hline
\end{tabular}


Père Joseph

Vieux-Bruges

Vieux-Bruxelles

Nazareth Classic

Mi-vieux de Bruges

Gouda with mustard seeds

$\mathrm{LOQ}^{*}=5.0 \mathrm{mg} \mathrm{NO}_{3}{ }^{-} / \mathrm{kg}$

$\mathrm{LOQ}^{* *}=6.67 \mathrm{mg} \mathrm{NO}_{2}^{-} / \mathrm{kg}$

${ }^{a}$ All analyses performed by the Scientific Institute of Public Health (2006). 
Table 3. Estimated habitual consumption of foods (g/day) in the Belgian population older than 15 years

\begin{tabular}{|c|c|c|c|c|c|}
\hline & \multirow[b]{2}{*}{ Mean } & \multicolumn{3}{|c|}{ Habitual consumption (g/day) } & \multirow{2}{*}{$\begin{array}{c}\text { Consumption days } \\
\% \\
\end{array}$} \\
\hline & & SD & $\mathrm{P} 50$ & $\mathrm{P} 97,5$ & \\
\hline Potatoes & 97.9 & 46.4 & 90.0 & 211.0 & 65 \\
\hline Soup & $\underline{93.3}$ & $\underline{89.0}$ & $\underline{77.0}$ & $\underline{296.0}$ & 35 \\
\hline Vegetables & 131.8 & 49.7 & $\underline{126.0}$ & 246.0 & 81 \\
\hline Tomato & 33.4 & $\overline{21.2}$ & 30.0 & 84.0 & 28 \\
\hline Carrot & 12.8 & 11.1 & 9.8 & 42.6 & 19 \\
\hline Chicory & 9.8 & 13.8 & 1.6 & 46.2 & 8 \\
\hline Lettuce (incl iceberg lettuce) & 8.3 & 6.9 & 6.5 & 26.6 & 21 \\
\hline Broccoli and cauliflower & 8.2 & 7.6 & 6.6 & 27.4 & 6 \\
\hline Onion & 6.6 & 4.5 & 5.7 & 17.9 & 25 \\
\hline Beans with pods & 5.9 & 4.9 & 4.6 & 18.6 & 7 \\
\hline Head cabbage & 4.2 & 2.9 & 3.6 & 11.7 & 4 \\
\hline Mushrooms & 4.2 & 3.9 & 3.1 & 14.9 & 8 \\
\hline Cucumber & 3.5 & 5.8 & 0.0 & 19.1 & 4 \\
\hline Spinach* & 3.1 & 20.3 & 0.0 & 52.0 & 3 \\
\hline Sweet pepper & 2.8 & 2.8 & 2.1 & 10.2 & 7 \\
\hline Leek & 2.3 & 2.9 & 1.4 & 10.3 & 4 \\
\hline Courgette & 1.8 & 2.1 & 1.2 & 7.5 & 2 \\
\hline Other (mixtures of) vegetables & 24.6 & 17.9 & 20.2 & 71.3 & 30 \\
\hline Fruits & 118.2 & $\underline{84.3}$ & $\underline{105.0}$ & $\underline{251.0}$ & 57 \\
\hline Apple & 39.0 & $\overline{39.8}$ & 30.0 & $\overline{135.0}$ & 27 \\
\hline Citrus fruit & 18.8 & 28.8 & 3.0 & 98.0 & 17 \\
\hline Banana & 14.5 & 22.1 & 0.0 & 73.0 & 9 \\
\hline Grapes & 6.0 & 13.7 & 0.0 & 46.4 & 4 \\
\hline Melon (excl water melon) & 4.9 & 10.4 & 0.0 & 35.7 & 2 \\
\hline Strawberry & 3.7 & 11.5 & 0.0 & 40.1 & 3 \\
\hline Mixed fruits & 2.5 & 9.7 & 0.0 & 36.0 & 1 \\
\hline Other fruits & 30.2 & 38.0 & 18.0 & 131.0 & 21 \\
\hline Cheese & $\underline{30.1}$ & 18.0 & $\underline{27.0}$ & $\underline{74.0}$ & 57 \\
\hline Meat products & $\underline{32.2}$ & 18.9 & 29.0 & $\overline{78.0}$ & 53 \\
\hline Nonalcoholic beverages & $\underline{1420.6}$ & $\underline{588.8}$ & $\underline{1336.0}$ & $\underline{2823.0}$ & 100 \\
\hline Mineral and source water & 541.1 & $\overline{448.2}$ & 451.0 & $\overline{1636.0}$ & 64 \\
\hline \multicolumn{6}{|l|}{ Other nonalcoholic beverages } \\
\hline Coffee and tea & 445.8 & 351.0 & 385.0 & 1331.0 & 75 \\
\hline Soft drinks & 212.3 & 260.9 & 134.0 & 911.0 & 37 \\
\hline Tap water & 97.1 & 206.9 & 0.0 & 716.0 & 19 \\
\hline Juices & 62.5 & 83.2 & 32.0 & 286.0 & 25 \\
\hline Beer & 122.1 & 228.6 & 0.0 & 778.0 & 17 \\
\hline
\end{tabular}

The habitual dietary intakes are weighted and adjusted for the age and

sex distribution of the Belgian population 2004 and adjusted for interview day and season.

Total number of consumption days is 6166

* Habitual intake could not be estimated by the Nusser method because of too few replicate intakes. 
Table 4. Estimated habitual nitrate intake ( $\mathrm{mg} / \mathrm{kg}$ bodyweight/day) in the Belgian population older than 15 years

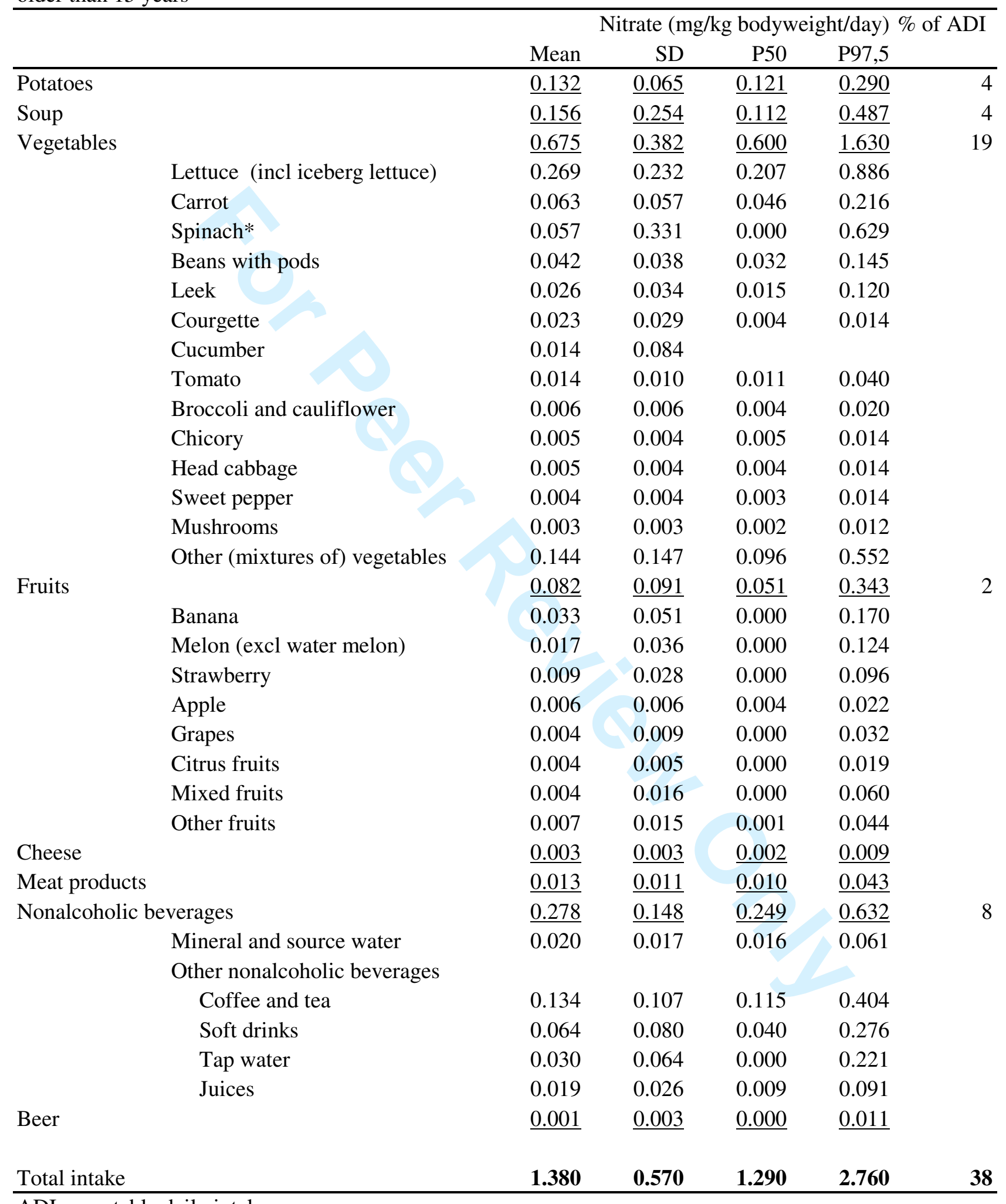

ADI acceptable daily intake

Nitrate expressed as nitrate ion, the acceptable daily intake (ADI) for nitrate is $3,65 \mathrm{mg} / \mathrm{kg}$ bw/day 
The habitual dietary intakes are weighted and adjusted for the age and sex distribution of the Belgian population 2004 and adjusted for interview day and season.

Total number of consumption days is 6166

* Habitual intake could not be estimated by the Nusser method because of too few replicate intakes. 
Table 5. Estimated habitual nitrite intake ( $\mathrm{mg} /$ day and $\mathrm{mg} / \mathrm{kg}$ bw/day) from meat products in Belgium for the total population

\begin{tabular}{lrrrrrrrrr}
\hline & \multicolumn{3}{c}{ Nitrite (mg/day) } & \multicolumn{5}{c}{ Nitrite (mg/day/kg bodyweight) } & \% of ADI \\
& Mean & SD & Mean & SD & Mean & SD & Mean & SD & \\
\hline Total meat products & 0.242 & 0.189 & & & 0.003 & 0.003 & & & \\
$\quad$ Ham sausages* & & & 0.037 & 0.282 & & & 0.001 & 0.004 & \\
Sausages boiled* & & & 0.030 & 0.277 & & & 0.000 & 0.004 & \\
Sausages raw meat* & & & 0.029 & 0.146 & & & 0.000 & 0.002 & \\
Sausages boiled in can* & & & 0.019 & 0.174 & & & 0.000 & 0.003 & \\
Poultry meat* & & & 0.014 & 0.111 & & & 0.000 & 0.002 & \\
Pate* & & & 0.011 & 0.076 & & & 0.000 & 0.001 & \\
Horse meat* & & & 0.010 & 0.089 & & & 0.000 & 0.001 & \\
\hline
\end{tabular}

acceptable daily intake

The average dietary intakes are weighted and adjusted for the age and

sex distribution of the Belgian population 2004 and adjusted for interview day and season.

The acceptable daily intake for nitrite is $0,07 \mathrm{mg} / \mathrm{kg}$ bw/day

* The habitual intake could not be estimated by the Nusser method because of too few replicate intakes. 